\title{
PARKING REQUIREMENT OF SHOPPING CENTERS
}

\begin{abstract}
The parking problem is a severe challenge in city planning because of its impact on road congestion and accidents, delay time, and cities' economy. therefore, many cities conducted different studies, reports, and projects to find the number of parking generation as it related to land use, in form equations, rates, and even data plots by using different independent variables. Iraq, till now, does not have a comprehensive study of parking requirements, or in specific how many parking spaces the different land uses are generated or needed. The general situation in Baghdad city at present is inadequate public transportation, few transportation alternatives, large private car use. besides the high illegal parking on the roads which means higher traffic density and congestion roads. this research studies three different shopping centers in Baghdad and analysis their parking generation as related to three different independent variables. these variables are GFA, GLA, and entertainment percentage where each variable is analyzed separately. the analysis was done based on parking accumulation in these sites. as it was counted manually for three days for Parking counting time that selected according to the peak of visitors for Retail is from $4 \mathrm{pm}-11 \mathrm{pm}$. in a result several parking generation rates and models with different forms are developed by using simple linear regression and only the best of them that has high R2 value and low RMSE is recommended. from the conclusion, the GFA and GLA have the most significant effect on parking generation as they developed strong models and rates. as these rates are 4.1 and 4.57 parking spaces for each $100 \mathrm{~m} 2$ of GFA and GLA respectively.
\end{abstract}

Keywords: Trip generation; Parking generation rate; shopping centers; parking requirement.

\author{
Noor Moutaz Asmael ${ }^{1}$ \\ ${ }^{1}$ Assist. Prof., Highway and Transportation Department, College of Engineering, Mustansiriyah \\ University,Baghdad,Iraq.Email:noor_moutaz@uomustansiriyah.edu.iq \\ Ghada Fahed Turky ${ }^{2}$ \\ ${ }^{2}$ Graduate student, Highway and Transportation Department, College of Engineering, Mustansiriyah \\ University, Baghdad, Iraq. Email; dosh18685@gmail.com
}

\section{Introduction}

The trips generation and parking demand rates or models one of the most important keys of cities urban planning, and states around the world always worked hard on produced the most suitable rates and models relied on their local conditions, regulations, and people habits, in a way that the produced rates and models fruition the highest benefits to the state. The rates and models assist the decision-makers like municipalities and ministries, in their planning decisions. By giving expected effects for the proposed project. For example, accepting, rejecting, or even modifying the parking demand as related to creating or changing the (development or land use), in a particular place.

Ignore provision parking generation rates for different land uses types, would-led to setting the number of parking spaces arbitrarily. So parking spaces will be either lower than required in this case there will be many negative effects as mentioned before. Or the parking spaces be more than needed, and this case is not desirable also. As it will cause land loss which can be used in other efficient ways. Besides, the economic losses. For example in 2017 san Francisco city made a comparative report of the parking area, the report concluded that approximately $28 \%$ of available parking spaces are not used as an average, which means which construction cost is 198,034,400 \$ are losses. (Chayan, 2018).

The general situation in Baghdad city in the present time is increasing construction shopping centers, poor public transportation, few transportation alternatives, a large private car using and high illegal parking on the roads, which means high traffic density and congestion roads. Since 2003, Baghdad city has seen many changes and developments; one of crucial change is the high inflation of car number, which caused the high pressure on the transportation network and parking areas besides many other problems like traffic congestion, increasing accidents, and air pollution (Asmael and Alkawaaz, 2019). Also, the other changes which have been in Baghdad city, are the high increase in construction of new shopping centers (malls) which also increase the number of employees, workers, and increase attraction activity which leads to congestion in the area around malls. These constructions are usually done randomly without sufficient study for urban and transportation planning or a study of required parking spaces for these malls. This insufficient planning and studies made the shopping centers and area around them from the first day are suffering from many problems like failure in providing sufficient parking spaces, pressure on the transportation network, and others. As Iraqi local parking studies are few. especially in the present, there is no specific study conducted to develop a parking generation model (equation or rates) for the new development as related to single land use where the existing studies have a different objective with a limited range.

\section{Background}

The literature studies produced parking demand generation rates for many land-use types. Parking demand is affected by the land use characteristics of that area (Parmar, Das, and Dave, 2020). The parking demand of individual retail stores varies with the size and type of store as well as its location, in a planned shopping center, 
or at an isolated point. A shopping mall can impact an area of over $50 \mathrm{~km}$ in radius, which its effect higher on the surrounding area (Regidor, 2007). The peak-hour parking generation average of small retail stores is 2.1 space per $1000 \mathrm{Sq}$. Ft. with range 0.9 to 3.8. (Academy of Science, 1971). The independent variables used in the ITE manuals are related to land use type and its characteristics, where several variables are used with the single land use, each variable produces a separate parking generation model. For example, in the 5th ITE manual, the used independent variables for the office and shopping center are.

- Office: employees, 1000 sq. ft. of GFA, occupied GFA, acre.

- $\quad$ Shopping center: 1000 sq. ft. GFA, employees, \% restaurant space, $\%$ entertainment space.

(Douglass and Abley, 2011) reported several parking generation rates for the retail sites relied on the site's
GFA and the type of the retail site supermarket, shopping centers, or large retail centers. For example, the suburban shopping center parking demand is 5 spaces per $100 \mathrm{~m} 2$ GFA for $10,000 \mathrm{~m} 2$ site areas. For the larger shopping center around $15,000 \mathrm{~m} 2 \mathrm{GFA}$, the parking demand variation is 2 to 4 spaces per $100 \mathrm{~m} 2$ GFA, as for the large retail centers, the parking demand rate is 3 parking spaces per $100 \mathrm{~m} 2$ of GFA. The report stated that the range of these averages is diverse depending on several factors like the catchment population, the promotion of the center, and the exposure to passing vehicle traffic. Also, the research stated that the parking demand shows reducing relationships with increasing the floor area. The following table shows different trip attractions across four countries

Table 1. Parking generation rates for the four countries New Zealand, Australia, the UK, and the USA. (Douglass and Abley, 2011)

\begin{tabular}{|l|l|l|l|l|l|l|l|}
\hline \multirow{2}{*}{ Land use } & \multicolumn{2}{|l|}{ New Zealand } & Australia & UK & \multicolumn{2}{l|}{ USA } \\
\cline { 2 - 8 } & Average & $85 \%$ & $85 \%$ & Average & $85 \%$ & Average & $85 \%$ \\
\hline $\begin{array}{l}\text { Commercial } \\
\text { premises/offices }\end{array}$ & $\begin{array}{l}2.7 / 100 \mathrm{~m}^{2} \\
\text { GFA }\end{array}$ & $\begin{array}{l}3.2 / 100 \mathrm{~m}^{2} \\
\text { GFA }\end{array}$ & $\begin{array}{l}2.5 / 100 \mathrm{~m}^{2} \\
\text { GFA }\end{array}$ & $\begin{array}{l}3.05 / 100 \mathrm{~m}^{2} \\
\text { GFA }\end{array}$ & $\begin{array}{l}5.02 / 100 \mathrm{~m}^{2} \\
\text { GFA }\end{array}$ & $\begin{array}{l}3.06 / 100 \\
\mathrm{~m}^{2}\end{array}$ & $\begin{array}{l}3.7 / 100 \\
\mathrm{~m}^{2}\end{array}$ \\
\hline $\begin{array}{l}\text { Shopping center } \\
\left(4000-10,000 \mathrm{~m}^{2}\right)\end{array}$ & $\begin{array}{l}3.3 / 100 \mathrm{~m}^{2} \\
\text { GFA }\end{array}$ & $\begin{array}{l}4.9 / 100 \mathrm{~m}^{2} \\
\text { GFA }\end{array}$ & $\begin{array}{l}5.5 / 100 \mathrm{~m}^{2} \\
\text { GLFA }\end{array}$ & $\begin{array}{l}5.64 / 100 \mathrm{~m}^{2} \\
\text { GFA }\end{array}$ & $\begin{array}{l}6.25 / 100 \mathrm{~m}^{2} \\
\text { GFA }\end{array}$ & $\begin{array}{l}3.25 / 100 \\
\mathrm{~m}^{2} \text { GLA }\end{array}$ & $\begin{array}{l}4.69 / 100 \\
\mathrm{~m}^{2} \mathrm{GLA}\end{array}$ \\
\hline
\end{tabular}

Al-Masaeid et al., 1999 (AL-MASAEID, ALOMARI, and AL-HARAHSHEH, 1999) recommended that parking space requirements must base on local conditions rather than using figures developed in other countries. This issue is very crucial to minimize the economic consequences of providing more or less than the optimal level of parking demand, particularly in cities where the cost of land or construction is relatively expensive. Al Ghanimy and Asmael 2020 (Al-Ghanimy and Asmael, 2020) stated that GFA is a primary factor that affects parking requirements for an educational building. Stein H. 1991 (STEIN, 1991) found that a base parking rate of 4.0 spaces per $1,000 \mathrm{ft} 2$ of GLA will enough for adequate parking during the year at almost all neighborhood and community shopping centers, regardless of most of the factors studied. The Mayoralty of Baghdad, the Design department, published several laws and regulations about the building of local Iraqi units, one of these regulations is the parking regulation that circulated to the municipalities in 2012. The regulation provides the number of parking spaces required for different land uses types. For example, from the regulation, the required parking spaces for supermarkets and malls are 5 spaces for every $100 \mathrm{~m} 2$.

The procedure of most studies depends on ITE manuals, with some changes that may use commensurate to their countries, conditions, experience in addition to other factors(Pi, Currans, and Muhs, 2012). Some studies have taken into account the seasonal variation, the transit impact, parking fees, the surrounding area type, and others. The institute of transportation engineer (ITE)(institute of transportation engineer, 2019) is considered one of the major organizations that published several parking generation manuals, which are used widely across the world as a point of reference to estimate the number of parking spaces to be supplied by the development. (McCourt, ITE 3rd Ed.) (McCourt, 2004).

\section{Sites Selection}

Baghdad city is the study area; several sites in different parts of Baghdad were selected for data collection, analysis, and model production. this research is focused on urban sites out of CBD area and some criteria were used for site selection like the site should be mature at least two years old, occupied at least by $(85 \%)$, the site should be clear and no abnormal condition besides it, and most importantly the site should have an obvious and specific parking lot.

The sample size concept should be appropriate and reasonable to give the best representation to the study area. The 4th ITE manual stated that a minimum of four sites for an individual land-use type should be provided for the best analysis and outputs. However, the total number of shopping centers in Iraq is six. According to the above criteria, only three of them are achieved it. So, they were adopted and used for data collection and model generation. The selected study sites and their location are presented in Table 2.

Table 2. Selected Shopping Centers and Their Location

\begin{tabular}{|l|l|}
\hline Site Name & Location \\
\hline Zayoona mall. & $\begin{array}{l}\text { Al-Rusafaa side. Zayonaa district. } \\
\text { Palestine street. }\end{array}$ \\
\hline
\end{tabular}




\begin{tabular}{|l|l|}
\hline $\begin{array}{l}\text { Al-Nakheel mall. } \\
\text { (NKH.) }\end{array}$ & $\begin{array}{l}\text { Al-Rusafaa side. Palestine street. } \\
\text { Port said street. }\end{array}$ \\
\hline $\begin{array}{l}\text { Baghdad mall. } \\
\text { (BGH.) }\end{array}$ & $\begin{array}{l}\text { Al-karkh side. Harthiya district. } \\
\text { Al-kindi street. }\end{array}$ \\
\hline
\end{tabular}

The following section is a brief description of the selected sites:

\section{A. Zayoona mall (ZY)}

It is the largest mall located on the Al-Rusfaa side, as shown in Fig 1. It is sited in a residential area, and its gate opens on a service street that separates from the major street. It is located near many shops and restaurants. This mall is more famous for young customers most of the weekdays than in other malls. The mall has several problems with its parking and its garage in a way that has an adverse effect on the adjacent street.

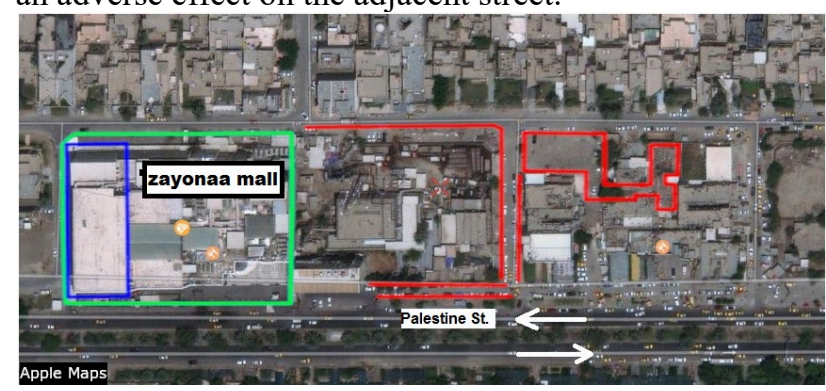

Fig 1. Zayonaa Mall location site and its surveyed parking areas

$$
\begin{aligned}
& \text { Color lines keys: } \\
& \text { Green: Site Boundaries } \\
& \text { Red: Outside Parking } \\
& \text { Blue: Inside Parking }
\end{aligned}
$$

\section{B. Al-Nakheel mall (NKH)}

This mall is located at the Al-russafa side, at Palestine Street, where two sides of it align Palestine street as shown in Fig 2. Also, there is a four legs intersection in front of it at a small distance and Palestine Street Bridge. Nearby it, there are many ministries whose employees represent the morning customers of the mall, but they are usually not gone by private cars. The public transportation can reach directly to it. The mall contains many shops, some of them are international brands, restaurants, cafes, in addition to four places dedicated to kids' games. This mall does not have a parking area. However, there are adjoins to it, a private 5-floor garage. Where this garage has its gate open in the mall.

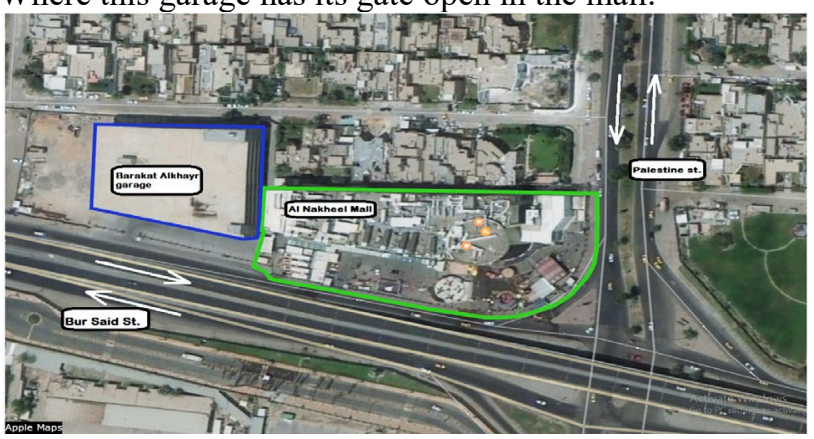

Fig 2. Al Nakheel Mall location site and its surveyed parking area

\section{Baghdad mall (BGH)}

This mall is located on the Al-karkh side, at the beginning of AL-Kindi Street, as shown in Fig 3. Nearby from it, many shops, restaurants, and doctor clinics. The mall design is divided into two parts, the larger mall building and the restaurants street, which includes more than 25 restaurants, besides, there are many shops located in the outer courtyard of the mall on the side of the mall building. The mall building, although it with a large area, but the number of the total shops inside it is not large. That due to the shops of international brands occupy large areas inside the building. The public transportation can reach directly to it.

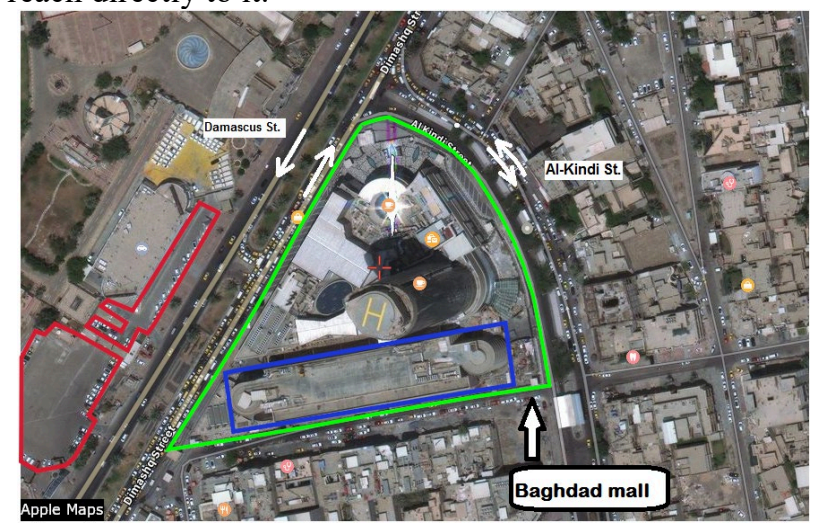

Fig 3. Baghdad Mall location site

\section{Data collection}

\section{Color lines keys: Green: Site Boundaries Blue: Outside Parking}

The data collection was done in two steps as follows:

1. Independent variables selection: The parking generation models and rates are used to predict the parking demand for a site, according to its land-use type. These models and rates are consists of independent variables, which vary with the land use type. The research selected independent variables used to generate the model and rates are:

Gross Floor Area (GFA): is the area within the external walls of a building, excluding any area dedicated to the parking of vehicles. including all common areas shared by customers when considers the joint retail areas

Gross Leasable Area (GLA): this area represents the leasable floor area in the developments designed for tenant occupancy and exclusive use. It is mostly used with supermarkets and various occupations stores, malls, and others. It is frequently used and commonly forms $80 \%$ of the GFA.

Entertainment Percentage (E\%): it represents the percentage of entertainment space (including that, restaurants, cafes, cinemas, kids, and adult games) to the total mall size. this variable is adopted from the ITE manual.

2. Field Surveys: this step was done to collect two types of data:

First type: site's properties data: it is the data about the selected independent variables Gross Floor Area 
(GFA), Gross Leasable Area (GLA), and Entertainment Percentage (E\%).

Second type: parking counts and inventories, the parking counts were done to calculate the parking demand at each site. According to Garber and Hoel, the parking demand is the accumulation of vehicles parked at a given site at any associated point in time. Therefore this survey is done in two steps:

A. Determination Counting periods and duration; This step is the major step in the counting of the parked vehicles accumulation for a particular site. Whereas every site has different times for parking demand, According to site land-use type, site activities, site work hours, etc. therefore, the ITE manual mentioned that the parking counts time must be connected with the study purpose. This study objective is to determine peak periods of parking demand ( $\max$ accumulation), for each site on particular days. Parking counting time for Retail land use in this research is from $4 \mathrm{pm}-11 \mathrm{pm}$. Besides, this study counts the parking demand for three days for each site

B. Counting the parking demand. This step is to count the parked vehicle accumulation at the sites, on a particular day. The ITE manual stated that the counting must cover the total site parking demand. This means all the parked vehicles related to the site, whether in the site, or parked vehicles out the site, in the public or private parking or on streets. The Hourly surveys were conducted at each site during the period $4 \mathrm{pm}-11 \mathrm{pm}$.

Determine the Maximum Average Parking Demand.

This average is the average of three days of the maximum parked vehicle accumulation at each site, it represents the parking demand in this research, which then it used in analyzing to develop parking generation models and rates.

\section{Collected data}

As mention before, in this research two types of data, were collected, the first about site properties, and the second about the parking surveys. As shown in tables 3 and 4 below

Table 3. Shopping Center Properties

\begin{tabular}{|l|l|l|l|l|}
\hline $\begin{array}{l}\text { Shopping } \\
\text { Center. } \\
\text { Name }\end{array}$ & $\begin{array}{l}\text { No. of } \\
\text { Parking Area }\end{array}$ & $\begin{array}{l}\text { GFA. } \\
\text { Per } 100 \\
\mathrm{~m}^{2}\end{array}$ & $\begin{array}{l}\text { GLA. } \\
\text { Per } 100 \\
\mathrm{~m}^{2}\end{array}$ & E \% \\
\hline Zayonaa & 1 & 99.5 & 88.91 & $33 \%$ \\
\hline Nakheel & 1 & 110.84 & 92.25 & $28 \%$ \\
\hline Baghdad & 1 & 164.82 & 152.67 & $42 \%$ \\
\hline
\end{tabular}

GFA $=$ total area - parking area. GLA; gross leasable area. From table 3 the gross floor area for shopping centers is not including the parking areas, the gross leasable area is the mall's area that can be rented (shops, restaurants, etc.). Approximately all the malls have close entertainment percentage because the malls somewhat have a similar design, and Baghdad mall has the largest entertainment percentage because the mall contains (AlNahr Street) which is a restaurants street that contains 15 restaurants approximately, besides the other restaurants and cafes in the mall building. These percentages, GFA, and GLA were taken from the malls' engineers.
The second type of the collected data is the parking demand and supply for each shopping center. As explained before the parking demand that used in this research is represents (the average of three days of max parking accumulation, that calculated in period $4 \mathrm{pm}-11$ $\mathrm{pm}$ ). as for parking supply represents the legal parking supply spaces, within the sites only, These parking spaces usually be marked and striped, and they were counted manually. however, the parking supply information does not directly participate in parking model generation. But it gives more clarification about parking demand phenomena to a specified site in general. As well, it can be used for comparison purposes. also, the ITE guide and some references recommended providing such information. The parking demand and supply for each shopping centers are present in table 4 .

Table 4. Number of parking supply spaces and parking demands for each shopping center

\begin{tabular}{|l|l|l|l|l|l|l|}
\multicolumn{7}{|c|}{ for each shopping center } \\
\begin{tabular}{|l|l|l|l|} 
Shoppin \\
g center
\end{tabular} & $\begin{array}{l}\text { Sup } \\
\text { ply }\end{array}$ & $\begin{array}{l}\text { Tim } \\
\text { e }\end{array}$ & $\begin{array}{l}\text { Off- } \\
\text { street } \\
\text { Parkin } \\
\text { g }\end{array}$ & $\begin{array}{l}\text { On- } \\
\text { street } \\
\text { parkin } \\
\text { g }\end{array}$ & $\begin{array}{l}\text { Parki } \\
\text { ng } \\
\text { Dema } \\
\text { nd }\end{array}$ & D/S \\
\hline Zayonaa & 172 & Pm & 212 & 186 & 398 & 2.29 \\
\hline Nakheel & 600 & Pm & 430 & 0 & 430 & 0.7 \\
\hline Baghdad & 482 & Pm & 512 & 186 & 698 & 1.45 \\
\hline
\end{tabular}

D/S: Demand/ supply ratio. Parking demand: ave. of three days max parking demand.

In general, many reasons are playing a role in determining the actual parking demand for malls. Like the visitor's transportation modes, malls' location in commercial or residential areas, the type of mall's stores and merchandise and prices, the population of areas near malls and their level of income, and also the ability of public transportation to reach them. for example, Zayona mall has a lot of visitors more than al-Nakheel mall but its visitors were coming by many modes of transportation like the public bus, taxis, and private cars or even walking unlike al-Nakheel and Baghdad mall as their visitors are more used to private cars than other modes of transportation.

The distribution of parking demand is the variation of the parking demand ratio for the various hour of the day divided by the peak parking demand ratio, expressed as a percentage. (100 percent represents the hour(s) of peak parking demand. (ITE 5th, manual, 2019). (Parking demand in an hour/ peak parking demand). table 5 display the parking demand distribution by each hour for each shopping center.

Table 5. Time of day parking distribution of shopping Ccenters

\begin{tabular}{|l|l|l|l|}
\hline Time range & Zayonaa & Nakheel & Baghdad \\
\hline $4-5$ PM & $25 \%$ & $12 \%$ & $20 \%$ \\
\hline $5-6$ PM & $51 \%$ & $38 \%$ & $45 \%$ \\
\hline $6-7$ PM & $95 \%$ & $72 \%$ & $78 \%$ \\
\hline $7-8$ PM & $100 \%$ & $91 \%$ & $100 \%$ \\
\hline $8-9$ PM & $95 \%$ & $100 \%$ & $98 \%$ \\
\hline $9-10$ PM & $92 \%$ & $86 \%$ & $94 \%$ \\
\hline $10-11$ PM & $75 \%$ & $58 \%$ & $82 \%$ \\
\hline
\end{tabular}


From Table 5, the parking demand variation of the three malls is somewhat close, the rush hours of the malls are from 6.30 p.m. to 9 p.m. where all the malls during this time see a very high number of visitors. After 9 p.m., the number of visitors continues, but some cars start to leave the mall and make space for other cars; therefore, the parking demand became lower. This variation of parking demand has been counted in the malls on the weekends of the summer season. For Baghdad and Zayonaa malls, their parking demand was causing greatly interrupted for adjacent main street traffic. The matter reached to occupy a two-lane that adjoining the main street.

Data analysis and models generation

The descriptive statistics such as mean, standard deviation, coefficient of variation, maximum and minimum values, and range were calculated for each variable, as shown in Table 6 below.

Table 6. Descriptive statistics for collected data for retail land use

\begin{tabular}{|c|c|c|c|c|c|c|}
\hline Variable & Mean & $\begin{array}{l}\text { std. } \\
\text { dev. } *\end{array}$ & $\begin{array}{l}\text { CV } \\
\% *\end{array}$ & $\begin{array}{l}\text { Maximu } \\
\mathrm{m}\end{array}$ & $\begin{array}{l}\text { Minimu } \\
\mathrm{m}\end{array}$ & $\begin{array}{l}\text { Rang } \\
\text { e }\end{array}$ \\
\hline $\begin{array}{l}\text { Entertainm } \\
\text { ent }(\%)\end{array}$ & 34.33 & 7.1 & 20.6 & $42 \%$ & $28 \%$ & $14 \%$ \\
\hline $\begin{array}{l}\text { GFA per } \\
100 \mathrm{~m}^{2 .}\end{array}$ & 125.1 & 35 & 27.8 & 164.82 & 99.50 & $\begin{array}{l}65.3 \\
2\end{array}$ \\
\hline $\begin{array}{l}\text { GLA per } \\
100 \mathrm{~m}^{2}\end{array}$ & $\begin{array}{l}111.2 \\
7\end{array}$ & 36 & $\begin{array}{l}32.2 \\
4\end{array}$ & 152.67 & 88.91 & $\begin{array}{l}63.7 \\
6\end{array}$ \\
\hline $\begin{array}{l}\text { Parking } \\
\text { demand } \\
\text { pm. }\end{array}$ & 509 & $\begin{array}{l}164.7 \\
5\end{array}$ & $\begin{array}{l}32.3 \\
7\end{array}$ & 698 & 398 & 300 \\
\hline
\end{tabular}

From Table 6, the variation values (Std. dev. And CV.) For all variables that are close and moderate, the CV values are ranging (20.6 to $33.4 \%)$. This closeness in dispersion values is related to the type of studied shopping centers, as they are convergent by their sizes, design, and features.

Besides the general design of shopping centers is very similar, depends on creating many entertainment places and using most of GFA for leasable purpose, thus the $\mathrm{CV}$ value of entertainment $\%$ is 20.6 , and the mean of GFA is close to the mean of GLA.

As for parking demand, the CV value is 32 percent, means low dispersion about the mean, and this related to the fact that all the shopping center are seeing a high and close number of visitors.

\section{Models Development}

This research explores the relationship between parking demand and different independent variables. the simple linear regression was used to produce parking generation models by using three independent variables that related to the retail land use. All forms of models were investigated, but only the most appropriate of models, with the best fit of the regression line, are presented which are linear, exponential, power, and logarithm models.

The best models with the high correlation (R2 values) and best statistical significance are then chosen, these models are used to calculate the parking demand for shopping centers. in this research, for retail land use the parking demand was counted only for the evening period because, in Iraqi shopping centers, the max parking accumulation occurs in the evening period. Therefore, the parking generation models were developed only for the evening periods by using the three selected independent variables, as shown in the subsections below.

\subsection{The entertainment percentage ( $\mathrm{E} \%)$}

The amount of entertainment (restaurants, cinemas, playgrounds, and others) in the shopping center is considered as one of the most trips attraction in the mall, particularly in Iraq, where the entertainment places are trending low. Therefore, the entertainment percentage is used to develop parking generation models for retail land use. Table 7 presents the developed models and their properties as shown below.

Table 7. Parking Generation Models (PM) and Their Properties for Variable Entertainment's Percentage (\%)

\begin{tabular}{|c|c|c|c|c|c|c|c|c|c|}
\hline No & Model Type. & Model & $\mathrm{R}^{2}$ & $\begin{array}{l}\text { Adj. } \\
R^{2}\end{array}$ & F- test & P-Value. & T-test & $\begin{array}{l}\text { P- } \\
\text { Value. }\end{array}$ & RMSE \\
\hline 1 & Linear & $\mathrm{P}=21 \mathrm{X}-220.3$ & 0.82 & 0.64 & 4.605 & 0.2 & $\begin{array}{l}2.146 \\
-0.465\end{array}$ & $\begin{array}{l}0.2 \\
0.6\end{array}$ & 98.4 \\
\hline 2 & Logarithm & $\mathrm{P}=713 \ln \mathrm{X}-2007$ & 0.78 & 0.56 & 3.506 & 0.3 & $\begin{array}{l}1.872 \\
-1.496\end{array}$ & $\begin{array}{l}0.3 \\
0.3\end{array}$ & 109.75 \\
\hline 3 & Power & $\mathrm{P}=\mathrm{X}^{1.313 * 4.772}$ & 0.75 & 0.52 & 3.129 & 0.3 & $\begin{array}{l}1.769 \\
0.382\end{array}$ & $\begin{array}{l}0.3 \\
0.7\end{array}$ & 0.214 \\
\hline 4 & Exponential & $\mathrm{P}=\mathrm{e}^{0.039 \mathrm{X} * 128}$ & 0.8 & 0.61 & 4.073 & 0.29 & $\begin{array}{l}2.018 \\
1.492\end{array}$ & $\begin{array}{l}0.29 \\
0.37\end{array}$ & 0.193 \\
\hline
\end{tabular}

From table 7 all the developed models show good R2 values ranging from 0.73 to 0.81 , but at the same time, they differ from the adj. R2 values by a large amount approximately $20 \%$. So, adj. R2 values are considered instead. The (adj. R2) values show acceptable $R 2$ values $(>0.5)$ for all models except the power model. According to the ITE manual $(\mathrm{R} 2>0.5)$ is acceptable. The good R2 values mean there is a good relationship between the parking demand and entertainment percentage for the shopping center. Furthermore, the RMSE values for linear and logarithm models are 102.88 and 114.12 respectively, where these high error values so weaken the predictive 
power of the models and affect their accuracy, so they are not recommended to be used. On the other hand, from the same Table, all the developed models are not significant at a $95 \%$ confidence interval, where all the models have ( $p$-value $>0.05)$. The small sample size also affects the model's significance, therefore, a lower confidence interval here may be appropriate.

However, all the developed models for the entertainment percentage variable are not recommended to be used, alternatively, rates can be used instead of them. Figure 4 displays the regression model plot of parking demand in the evening period vs. entertainment percentage for shopping centers. From the figure, the points have a large deviation distance from the regression line, the line worse fit.

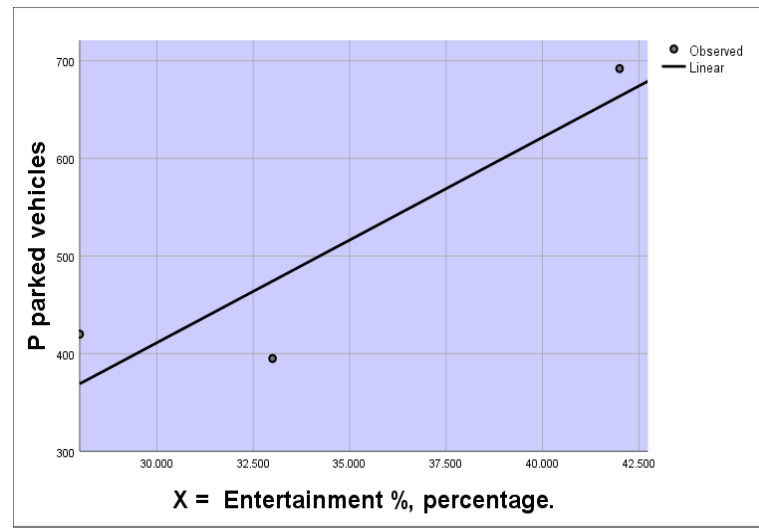

Fig 4. Model plot of parking demand (PM) vs. entertainment percentage for retail land use.

\subsection{Gross Floor Area (GFA)}

The shopping center's gross floor area is the second variable used to develop the models for retail land use. As shown in Table 8 , the developed models and their properties.

From table 8, all the developed models have high $\mathrm{R}^{2}$ $>0.95$, indicates to the strong models and strong relationship between the shopping center GFA and parking demand. Also, the RMSE values for all models are acceptable, especially for the power and exponential models; their error is 0.029 and 0.01 , respectively. As for models significant show up that at a $0.95 \%$ confidence interval, all the models are significant except the logathrim model. The p-value of the logarithm model is 0.06 and that affects the model significantly, so the logarithm model is not recommended to be used. Figure 5 displays the regression model plot of parking demand of the evening period vs. the shopping center GFA, for retail land use. From the figure, the points are distributed very well around the regression line, low deviations from the line indicate a strong relationship.

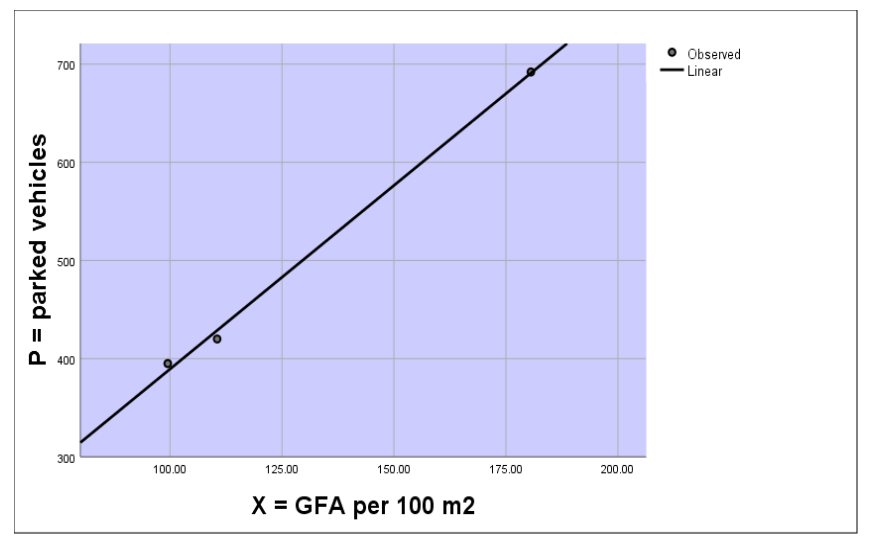

Fig 5. Model plot of parking demand (PM) vs. site GFA for retail land use.

Table 8. Parking generation models (PM) and their properties for variable site's GFA

\begin{tabular}{|c|c|c|c|c|c|c|c|c|c|}
\hline No & Model Type. & Model & $\mathrm{R}^{2}$ & $\begin{array}{l}\text { Adj. } \\
\mathrm{R}^{2}\end{array}$ & F- test & $\begin{array}{l}\text { P- } \\
\text { Value }\end{array}$ & T-test & $\begin{array}{l}\text { P- } \\
\text { Value }\end{array}$ & RMSE \\
\hline 1 & Linear & $P=4.7 X-80$ & 0.99 & 0.99 & 229.578 & 0.04 & $\begin{array}{l}15.152 \\
-2.012\end{array}$ & $\begin{array}{l}0.04 \\
0.3 \\
\end{array}$ & 15.34 \\
\hline 2 & Logarithm & $P=616 \ln X-2452$ & 0.99 & 0.98 & 86.346 & 0.06 & $\begin{array}{l}9.292 \\
-7.688\end{array}$ & $\begin{array}{l}0.06 \\
0.08\end{array}$ & 24.93 \\
\hline 3 & Power & $\mathrm{P}=\mathrm{X}^{1.14} * 2$ & 0.99 & 0.97 & 167.388 & 0.049 & $\begin{array}{l}12.938 \\
2.355 \\
\end{array}$ & $\begin{array}{l}0.049 \\
0.3 \\
\end{array}$ & 0.033 \\
\hline 4 & Exponential & $\mathrm{P}=\mathrm{e}^{0.009 \mathrm{X} *} 165.5$ & 0.99 & 0.99 & 777.923 & 0.023 & $\begin{array}{l}27.89 \\
24.94 \\
\end{array}$ & $\begin{array}{l}0.023 \\
0.026 \\
\end{array}$ & 0.015 \\
\hline
\end{tabular}

\subsection{Gross Leasable Area (GLA)}

The shopping centers' gross leasable area is the third variable used to develop parking generation models for retail land use, as shown in Table 9 that presented the developed models and their properties.
From table 9, all the developed models have a high $\mathrm{R}^{2}$ equal to 0.99 , which indicated the very high relationship between the shopping center's parking demand and its gross leasable area. Also, the RMSE values for all developed models are low and acceptable. Further from the same table, all the models are significant at a $95 \%$ confidence interval. So, the developed models 
for GLA are strong models for prediction, and all of them are recommended to be used.

Figure 6 displays the regression model plot of the parking demand for the evening period and shopping centers' gross leasable area. From the figure, the regression line has fitted the points very well.

Table 9. Parking Generation Models (PM) and Their Properties for Variables Sites' GLA

\begin{tabular}{|c|c|c|c|c|c|c|c|c|c|}
\hline No & Model Type. & Model & $\mathrm{R}^{2}$ & $\begin{array}{l}\text { Adj. } \\
\mathrm{R}^{2} \\
\end{array}$ & F- test & $\begin{array}{l}\text { P- } \\
\text { Value } \\
\end{array}$ & T-test & $\begin{array}{l}\text { P- } \\
\text { Value }\end{array}$ & RMSE \\
\hline 1 & Linear & $\mathrm{P}=4.58 \mathrm{X}-1.52$ & 0.99 & 0.99 & 388.057 & 0.032 & $\begin{array}{r}19.699 \\
-0.057\end{array}$ & $\begin{array}{l}0.03 \\
0.9\end{array}$ & 11.81 \\
\hline 2 & Logarithm & $P=545 \ln X-2042$ & 0.99 & 0.99 & 762.786 & 0.023 & $\begin{array}{l}27.619 \\
-22.081\end{array}$ & $\begin{array}{l}0.023 \\
0.024\end{array}$ & 8.43 \\
\hline 3 & Power & $\mathrm{P}=\mathrm{X} * 4.45$ & 0.99 & 0.99 & 227.128 & 0.04 & $\begin{array}{l}15.071 \\
3.197 \\
\end{array}$ & $\begin{array}{l}0.04 \\
0.1 \\
\end{array}$ & 0.029 \\
\hline 4 & Exponential & $\mathrm{P}=\mathrm{e}^{0.008 \mathrm{X} * 199}$ & 0.99 & 0.99 & 152.563 & 0.05 & $\begin{array}{l}12.352 \\
12.693 \\
\end{array}$ & $\begin{array}{l}0.05 \\
0.05 \\
\end{array}$ & 0.035 \\
\hline
\end{tabular}

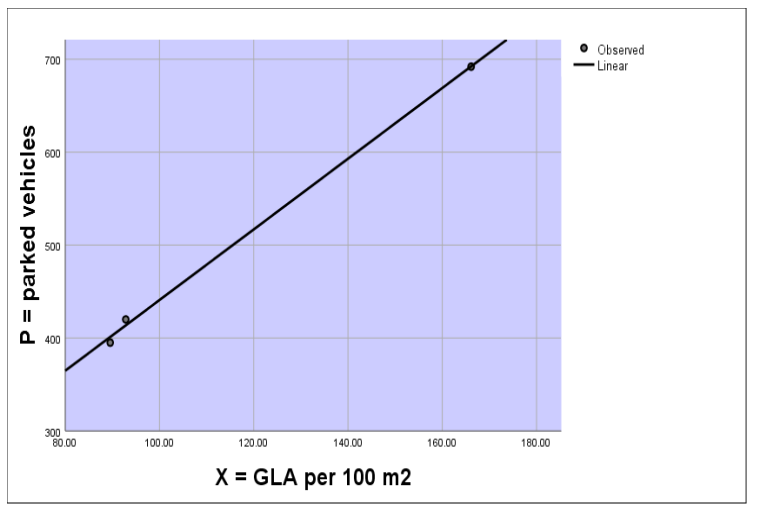

Fig 6. Model Plot of Parking Demand (PM) vs. Site GLA for Retail Land Use.

\section{Parking generation rates}

These rates are represented by the weighted mean, they are most predominately used across the world like the USA, UK, and other countries. The rates are used when the model is not efficient predictive of parking generation.

The parking generation rates in table 10 are produced by using the same variables that were used to develop the models earlier. The statistical dispersion measurements for the weighted mean were also calculated and presented, these measurements illustrated the variation of the data and the differences between the data value and the mean. As the smaller dispersion the better rates. For example the parking generation rate for gross floor area is = (total gross floor areas/ total parking demand), which equal $(99.5+110.84+164.82) /(398+430+698)=4.1$ vehicle (space) per $100 \mathrm{~m} 2$ of GFA. As for the rate, the range represents the parking generation rate for each shopping center, the highest and lowest rates between them.

Table 10. Parking Generation Rates

\begin{tabular}{|c|c|c|c|c|c|c|}
\hline \multicolumn{7}{|c|}{ Retail land use. } \\
\hline No. & Period & Rates & Range & Std. dev. & CV\% & Rates Range \\
\hline 1 & \multirow{3}{*}{ PM } & $\begin{array}{l}14.82 \text { spaces per entertainment's } \\
\%\end{array}$ & 4.558 & 2.354 & 15.9 & $12.1-16.6$ \\
\hline 2 & & 4.1 spaces per $100 \mathrm{~m}^{2}$ of GFA. & 0.355 & 0.181 & 4.4 & $3.88-4.2$ \\
\hline 3 & & 4.57 spaces per $100 \mathrm{~m}^{2}$ of GLA. & 0.185 & 0.092 & 2 & $4.5-4.7$ \\
\hline
\end{tabular}

Statistically: the produced models and rates are must verified by using new data but For retail land use there is no valid data to verify them, for several reasons. The overall number of shopping centers in Baghdad city is six; three of them are studied and used to develop parking generation rates and models in this research. The remain is three shopping centers, one of the is AL- Waha mall which is a small shopping center with GFA $1750 \mathrm{~m} 2$, this mall is dependent mostly on morning demand from the employees and students because of its location surrounded by several ministries and universities. so, For the evening period, there is low demand, so it is not similar to the state of studied shopping centers. As for the two other shopping centers are Babylon mall and al Mansour mall, they have no specific parking lot or garage; their customers are using the public parking lots distributed in the region. Further, they are located on Commercial Street with many shops and restaurants, and there is no way to know the actual parking demand for them.

\section{Recommended models and rates}

The best models and rates are selected and recommended for each variable. The best model selection is made based on R2 values (the highest value), confidence level (significant at 95\%), the model's error of estimate (the lowest error), residuals plot and test (normal distribution), and models and rates verification (differences $<30 \%$ ). Relying on all the above, the recommended models and rates for retail land use are presented in Table 11. 
Table 11. Recommended Parking Generation Models and Rates

\begin{tabular}{|c|c|c|c|c|c|}
\hline Time & No. & Parameter. & Models & $\mathrm{R}^{2}$ & Rates \\
\hline \multirow[t]{3}{*}{$\mathrm{Pm}$} & 2 & $\begin{array}{l}\text { Entertainment } \\
\% \text {. }\end{array}$ & - & - & 14.82 \\
\hline & 3 & GFA per $100 \mathrm{M}^{2}$ & $\begin{array}{ll}\mathrm{P} & = \\
\mathrm{e}^{0.009 \mathrm{X}} & * \\
165.5 & \end{array}$ & 0.99 & 4.1 \\
\hline & 4 & $\begin{array}{lll}\text { GLA } & \text { per } & 100 \\
\mathrm{M}^{2} & & \end{array}$ & $\begin{array}{l}\mathrm{P}= \\
\mathrm{e}^{0.008 \mathrm{X} *} \\
199\end{array}$ & 0.99 & 4.57 \\
\hline
\end{tabular}

From the above table, no models are recommended for the variable entertainment percentage because all of its models were insignificant,

rates can be used instead of them. As for the other variables, the models and rates are recommended, use any of them are applicable, but the models statistically are more favorable.

\section{Parking supply rates}

It is the parking supply ratio according to the ITE manual is the number of spaces per independent variable. (Spaces per employee, spaces per 100 sq. m. of GFA, or any other variable). This ratio is based on the total supply spaces for the site, rather than the occupied spaces. For example for (ZYM.) shopping center the parking supply rate per GFA is $(172 / 99.4=1.73$ space per person), per is $(269 / 2432=0.111$ space per employ), and per $100 \mathrm{~m} 2$ of GFA is $(269 / 1878.64=0.14$ space per $100 \mathrm{~m} 2)$, and so on for other sites. The parking supply ratio for each site and independent variable is presented in Table 12 below.

Table 12. Parking supply rates for shopping centers.

\begin{tabular}{|l|l|l|l|l|}
\hline $\begin{array}{l}\text { Shopping } \\
\text { center } \\
\text { Name }\end{array}$ & Supply & Entertainment \% & GFA & GLA \\
\hline ZYM. & 172 & 6.18 & 1.73 & 1.93 \\
\hline NKHM. & 600 & 21.4 & 5.41 & 6.5 \\
\hline BGHM. & 482 & 11.5 & 2.92 & 3.16 \\
\hline
\end{tabular}

\section{Comparison and discussion}

The developed parking generation rates in this research are produced relied on Iraqi field survey data for each site, as these rates simulate the actual situation for parking demand in Iraqi malls. These rates are compared with the rates suggested by the majority of Baghdad (local regulation), and the rates of the ITE 5th manual, and Palestine to show up how much the differences between them if existed. Tables 13 and 14 below are present these comparisons.

Table 13. Comparing Obtained Parking Generation Rates Vs. Iraqi Regulation Rates

\begin{tabular}{|l|l|}
\hline Developed parking rates & Local regulation \\
\hline 4.1 spaces per $100 \mathrm{~m}^{2}$ & 5 spaces per $100 \mathrm{~m}^{2}$ \\
\hline
\end{tabular}

Table 14. Comparing Obtained Parking Generation Rates vs. Palestine and (ITE $5^{\text {th }}$ ) Rates

\begin{tabular}{|l|l|l|}
\hline $\begin{array}{l}\text { Developed } \\
\text { parking rates }\end{array}$ & ITE $5^{\text {th }}$ Rates & Palestine Rates \\
\hline $\begin{array}{l}4.57 \text { spaces per } \\
100 \mathrm{~m}^{2} \text { of GLA. }\end{array}$ & $\begin{array}{l}3 \text { spaces per } 100 \mathrm{~m}^{2} \\
\text { Of GLA. }\end{array}$ & $\begin{array}{l}2.25 \text { spaces per } \mathrm{m}^{2} \\
\text { Of GLA. }\end{array}$ \\
\hline
\end{tabular}

The displayed comparison in Table 14 shows the retail parking generation rate is 4.57 space for each 100 $\mathrm{m}$, which is higher than the ITE and Palestine's rates. This is natural because the number of visitors to the shopping centers in Iraq is usually very high, because of the high attraction of these shopping centers. That is related to several reasons like, there are a few numbers of shopping centers in Baghdad and Iraq in general, the shopping center design that contains the cinemas' halls, playground halls for kids, several numbers of restaurants as well as the number of shops. Also, the number of entertainment places in Iraq is few, for example, there are no independent cinemas halls or several playgrounds for kids, and that's what made the shopping centers in Iraq are highly attractive for the visitors. Besides, Iraqi shopping centers are usually contained particular supermarkets that offer special goods and provide certain offers for their customers, besides mall special offers and others.

Moreover, another comparison of the developed parking generation rates with parking supply rates presented in Table 12. shows that the two malls' zayonaa and Baghdad parking supply ratios very lower than the recommended parking generation rates in this research, for example, in relied on GLA the parking supply ratios for Zayonaa and Baghdad malls are (1.93 and 3.16 space / $100 \mathrm{~m}$ ) respectively from Table 12 , as compared with the recommended parking rates is 4.57 space / $100 \mathrm{~m}$. This means the two malls have inadequate parking spaces and that also what has been noticed during the field survey where the parked vehicles fill up the garage and float to the adjacent roads. Al-Nakheel mall has a high supply ratio more than recommended in this research, and that was also noticed in the field survey as there were many empty parking spaces.

\section{Conclusion}

The following points concluded from the study

1. The parking modeling is essential, because of its impact on the planning, development, and management of the cities and their transportation network. The developed rates are simulating the Iraqi reality travel pattern.

2. The entertainment percentage produced insignificant parking generation models.

3. The GFA and GLA are the most predominant independent variable that has a strong power to predict parking generation rate for shopping centers.

4. Exponential and power models were the best forms that express the relationship between the parking demand and different variables. As they produced lower error and high R2 values. 
5. Higher parking generation rates for retail land use (14.82 space per Entertainment (\%), 4.1 space per 100 $\mathrm{m} 2$ of GFA, and 4.6 space per $100 \mathrm{~m} 2$ of GLA). That indicates the high proportion of trips for entertainment purposes. Accordingly, careful planning is required when constructing malls because they generate a high number of trips compared to other land uses.

6. The obtained parking generation rates are a high difference from local regulation and intentional or regional parking generation rates. Besides, to their differences by large amount with the provided parking supply rates at each site. As only Al-Nakheel mall had a sufficient parking supply rate.

\section{Acknowledgment}

The authors want to thank Mustansiriyah university for the opportunity of doing the research.

\section{References}

Al-Ghanimy, G. F. and Asmael, N. M. (2020) 'Estimate parking generation rates for educational sites', IOP Conference Series: Materials Science and Engineering, 745(1). doi: 10.1088/1757899X/745/1/012151.

AL-MASAEID, H., AL-OMARI, B. A. and ALHARAHSHEH, A. (1999) 'Vehicle Parking Demand for Different Land Uses in Jordan', ITE JOURNAL ON THE WEB, (May).

Asmael, N. M. and Alkawaaz, N. G. A. (2019) 'The Influence Change of Private Car Ownership on Patterns of Mode Choice in Baghdad city The Influence Change of Private Car Ownership on Patterns of Mode Choice in Baghdad city', IOP Conf. Series: Materials Science and Engineering, 518. doi: 10.1088/1757-899X/518/2/022025.

Douglass, M. and Abley, S. (2011) Trips and parking related to land use.

Institute of transportation engineer (2019) Parking Generation. 5th editio.

McCourt, R. S. (2004) Parking Generation.

Parmar, J., Das, P. and Dave, S. M. (2020) 'Study on demand and characteristics of parking system in urban areas: A review', Journal of Traffic and Transportation Engineering (English Edition). Elsevier, 7(1), pp. 111-124.

Pi, K. J. C., Currans, K. M. and Muhs, C. D. (2012) 'CONTEXTUAL INFLUENCES ON TRIP GENERATION Final Report by', (August).

Regidor, J. R. F. (2007) 'Development of philippine trip generation rates', Proceedings of the Eastern Asia Society for Transportation Studies, 6, p. 13.

STEIN, H. s. (1991) 'Parking Study of Neighborhood and Community Shopping Centers', TRANSPORTA T!ON RESEARCH RECORD. Transportation Research Board, (1299), pp. 19-27. 